\title{
COXEN Score 28
}

National Cancer Institute

\section{Source}

National Cancer Institute. COXEN Score 28. NCI Thesaurus. Code C128225.

A score of 28 on the COXEN Sensitivity Scale. 